inexpensive and provides a new technique for the diagnosis of non-immunologically mediated bronchial hyperreactivity.

This work was supported by a grant from the Asthma Foundation of New South Wales.

Requests for reprints should be sent to SDA.

\section{References}

${ }^{1}$ Curry JJ. Comparative action of acetyl-beta methylcholine and histamine on the respiratory tract in normals, patients with hay fever and subjects with bronchial asthma. $\mathcal{F}$ Clin Invest $1947 ; 26: 430-8$.

${ }^{2}$ Anderson SD, Silverman M, Godfrey S, Konig P. Exercise-induced asthma; a review. Br $\mathcal{F}$ Dis Chest $1975 ; 69: 1-39$.
${ }^{3}$ Deal EC, McFadden ER, Ingram RH, Breslin FJ, Jaeger JJ. Airway responsiveness to cold air and hyperpnea in normal subjects and in those with hay fever and asthma. Am Rev Resp Dis 1980;121:621-8.

${ }^{4}$ Allegra L, Bianco S. Non-specific broncho-reactivity obtained with an ultrasonic aerosol of distilled water. Eur $\mathcal{F}$ Respir Dis 1980;61, suppl 106: 41-9.

${ }^{5}$ Chai H, Farr RS, Froehlich LA, et al. Standardisation of bronchial inhalation challenge procedures. F Allergy Clin Immunol 1975;56:323-7.

${ }^{6}$ Duncan DB. Multiple range and multiple F-tests. Biometrics $1955 ; 11: 1-42$.

${ }^{7}$ Cheney FW, Butler J. The effects of ultrasonically-produced aerosols on airway resistance in man. Anesthesiology 1968;29:1099-106.

${ }^{8}$ Kaliner M, Austen KF. Cyclic AMP, ATP and reversed anaphylactic histamine release from rat mast cells. $\mathcal{f}$ Immunol 1974;112:664-74.

9 Findlay SR, Lichtenstein LM. Basophil "releasability" in patients with asthma. Am Rev Respir Dis 1980;122:53-9.

(Accepted 7 September 1981)

\title{
DR antigens and rheumatoid arthritis: a study of two populations
}

\author{
J C WOODROW，F E NICHOL，G ZAPHIROPOULOS
}

\begin{abstract}
The prevalence of HLA-DR antigens was determined in a group of white patients with rheumatoid arthritis, similar patients originating from the Indian subcontinent, and corresponding controls. Rheumatoid arthritis was found to be highly associated with DR4 in the white patients but with DR1 in the Indian patients.

These results raise the possibility that the DR antigens themselves do not play a part in increasing susceptibility to rheumatoid arthritis, but the locus for increased susceptibility is probably closely linked to the DR locus.
\end{abstract}

\section{Introduction}

An association has been shown between HLA-DR4 and rheumatoid arthritis. ${ }^{1-3}$ The populations studied have been largely European or of European origin. When an HLA antigen is shown to be positively associated with a disease two main possibilities arise. Firstly, the HLA antigen itself may play a direct part in producing increased susceptibility. Secondly, the association may arise because the susceptibility gene is not that determining the HLA antigen itself but is present at a locus within the HLA region and is in linkage disequilibrium with the gene for the HLA antigen. Supportive evidence for this second concept is afforded when what appears to be the same disease is associated with different HLA antigens in different ethnic populations. To elucidate this further with regard to rheumatoid arthritis we tested for their DR phenotypes two ethnically different groups of patients and corresponding healthy controls.

\footnotetext{
University Department of Medicine, Royal Liverpool Hospital, Liverpool L69 3BX

J C WOODROW, MD, FRCP, professor
}

Leicester Royal Infirmary, Leicester

F E NICHOL, MD, MRCP, senior registrar in rheumatology

Coventry and Warwickshire Hospital, Coventry CV1 4FH

G ZAPHIROPOULOS, MRCP, consultant rheumatologist

\section{Patients and methods}

Two separate studies were carried out and the results analysed together. In the Liverpool study DR typing was carried out in 100 consecutive white patients with seropositive erosive rheumatoid arthritis attending a rheumatology clinic. Typing was also carried out on blood samples from 100 healthy subjects (medical, nursing, and laboratory staff) living in the same geographical area.

In the Midlands study DR typing was similarly carried out in $\mathbf{3 5}$ patients originating from the Indian subcontinent and having seropositive rheumatoid arthritis. Typing was also performed in 42 healthy controls of the same ethnic origin living in the same geographical area.

DR typing was done in one laboratory (department of medicine, Liverpool University) by means of a cytotoxicity technique using an adaptation of the two-colour fluorescence method. ${ }^{4}$ The panel of sera used permitted typing for seven DR specificities. The relative risks were calculated using Haldane's modification of the Woolf method. ${ }^{5}$ The derived probability values $(\mathrm{p})$ are twice the $\mathrm{p}$ values obtained from the normal probability integral, giving values almost identical with those obtained with Fisher's exact test. Taking into account that seven antigens were tested for, a significant association was associated with a $\mathrm{p}$ value of 0.007 or less.

\section{Results}

Table I shows the numbers of patients and controls positive for each DR antigen in the two series. In the Liverpool study there was a highly significant positive association with DR4, the relative risk of a person positive for DR4 getting rheumatoid arthritis being 4.56 $\left(p=0.61 \times 10^{-6}\right)$. There was a non-significant increase in the relative risks associated with DR1 and DR3. The relative risks for DR6 and DR7 were 0.22 and 0.37 respectively, and the corresponding $p$ values of 0.005 and 0.0067 suggest that the negative associations were real. In the Midlands study a significant positive association was found with DR1, with a relative risk of $7.0(p=0.0022)$. There was a small non-significant increase in the prevalence of DR4. No significant negative associations were found.

Table II gives the outcome of statistical analysis of the results in the two series. There was significant heterogeneity between the two populations in respect of DR1 $(p=0.013)$ and DR4 $(p=0.049)$.

\section{Discussion}

The main finding in this study was the significantly different patterns of association of DR antigens with rheumatoid 
arthritis between the two ethnically different populations. In the indigenous white population rheumatoid arthritis was significantly associated with the presence of DR4 and there was evidence of a negative association with DR6 and DR7. In contrast, in the Indian immigrant population the disease was significantly associated with DR1 and not with DR4.

These findings support the concept that HLA-linked susceptibility genes for rheumatoid arthritis may not be the patterns of association between DR phenotypes and rheumatoid arthritis argues for the susceptibility genes not being those that determine the DR antigens themselves.

Evidence is accumulating of the existence of more than one locus at which Ia molecules are determined within the $D / D R$ region, homologous to the loci in the I region of the mouse $\mathrm{H}-2$. It has recently been suggested that the DR molecules may correspond to the I-E molecules of the mouse. ${ }^{910}$ There is

TABLE I-Prevalence of DR antigens in white subjects (Liverpool study) and subjects from Indian subcontinent (Midlands study)

\begin{tabular}{|c|c|c|c|c|c|c|c|c|}
\hline \multirow[b]{2}{*}{ Antigen } & \multicolumn{4}{|c|}{ Liverpool study } & \multicolumn{4}{|c|}{ Midlands study } \\
\hline & $\begin{array}{c}\text { No of } \\
\text { patients } \\
\text { positive } \\
(\mathrm{n}=100)\end{array}$ & $\begin{array}{c}\text { No of } \\
\text { controls } \\
\text { positive } \\
(\mathrm{n}=100)\end{array}$ & $\begin{array}{c}\text { Relative } \\
\text { risk }\end{array}$ & $\mathrm{p}$ & $\begin{array}{l}\text { No }(\%) \text { of } \\
\text { patients } \\
\text { positive } \\
(\mathrm{n}=35)\end{array}$ & $\begin{array}{l}\text { No }(\%) \text { of } \\
\text { controls } \\
\text { positive } \\
(\mathrm{n}=42)\end{array}$ & $\begin{array}{c}\text { Relative } \\
\text { risk }\end{array}$ & $\mathrm{p}$ \\
\hline $\begin{array}{l}\text { DR1 } \\
\text { DR2 } \\
\text { DR3 } \\
\text { DR4 } \\
\text { DR5 } \\
\text { DR6 } \\
\text { DR7 }\end{array}$ & $\begin{array}{r}28 \\
21 \\
29 \\
74 \\
3 \\
4 \\
14\end{array}$ & $\begin{array}{l}20 \\
25 \\
20 \\
38 \\
11 \\
17 \\
31\end{array}$ & $\begin{array}{l}1.54 \\
0.80 \\
2 \cdot 19 \\
4.56 \\
0.28 \\
0.22 \\
0.37\end{array}$ & $\begin{array}{l}0.25 \\
0.61 \\
0.19 \\
0.61 \times 10^{6} \\
0.05 \\
0.005 \\
0.0067\end{array}$ & $\begin{array}{r}21(60 \cdot 0) \\
15(42 \cdot 9) \\
3(8 \cdot 6) \\
6(17 \cdot 1) \\
6(17 \cdot 1) \\
7(20 \cdot 0) \\
7(20 \cdot 0)\end{array}$ & $\begin{array}{r}7(16 \cdot 7) \\
15(35 \cdot 7) \\
12(28 \cdot 6) \\
6(14 \cdot 3) \\
12(28 \cdot 6) \\
14(33 \cdot 3) \\
8(19 \cdot 0)\end{array}$ & $\begin{array}{l}7 \cdot 0 \\
1 \cdot 3 \\
0 \cdot 3 \\
1 \cdot 2 \\
0 \cdot 5 \\
0 \cdot 5 \\
1 \cdot 1\end{array}$ & $\begin{array}{l}0.0022 \\
0.69 \\
0.05 \\
0.98 \\
0.36 \\
0.29 \\
1.00\end{array}$ \\
\hline
\end{tabular}

TABLE II-Results of statistical analysis comparing findings in the two series

\begin{tabular}{lrlcl}
\hline & $\begin{array}{c}\text { Combined } \\
\chi^{2}\end{array}$ & $\mathrm{p}$ & $\begin{array}{c}\chi^{2} \text { for } \\
\text { hetero- } \\
\text { geneity }\end{array}$ & $\mathrm{p}$ \\
\hline DR1 & 9.93 & 0.016 & 6.15 & 0.013 \\
DR2 & 0.03 & 0.86 & 0.84 & 0.36 \\
DR3 & 0.1 & 0.76 & 6.66 & 0.01 \\
DR4 & 21.32 & $0.39 \times 10^{-5}$ & 3.89 & 0.049 \\
DR5 & 5.26 & 0.022 & 0.67 & 0.4 \\
DR6 & 8.48 & 0.004 & 1.32 & 0.25 \\
DR7 & 5.35 & 0.02 & 2.66 & 0.10 \\
\hline
\end{tabular}

genes determining the DR antigens themselves. Such a gene or genes may well be the same in the two different populations but have a differing pattern of linkage disequilibrium with the various alleles of the $\mathrm{DR}$ locus.

A positive association with DR4 has now been found in populations of wide ethnic diversity-namely, Caucasians, Japanese, and American blacks. ${ }^{36}$ Most of the studies carried out in these populations also give some evidence of a small positive association with $\mathrm{DR} 1$, and a combination of 14 reports $^{23-8}$ gives a combined relative risk for DR1 of 1.46 $\left(\chi^{2}=13.4, p=2.5 \times 10^{-10} ; \chi^{2}\right.$ for heterogeneity $\left.=19.5, p=0 \cdot 1\right)$. In contrast, a small study ${ }^{3}$ of patients of Ashkenazim origin with rheumatoid arthritis gave the relative risk associated with DR1 of 8.3 , a figure similar to that for the Indian Asians, with no evidence of a significant association with DR4.

When one HLA antigen is positively associated with a disease it is to be expected that the antigens determined by the other alleles of the same locus will show, to a greater or lesser degree, a negative association when compared with all other antigens. In the present study there was evidence of an appreciable negative association with DR6 and DR7 in the white patients and controls, though the pattern in the Indian population was somewhat different, with DR3 showing a relative risk of 0.3 $(\mathrm{p}=0.005)$. Analysis of various reported studies suggests that DR2 is negatively associated with rheumatoid arthritis in white Caucasian populations (though not significantly in the present study) but not in Asian, Indian, or Jewish populations. It is too early to be sure what exactly is the true pattern of negative associations in different ethnic groups.

A strong indication that the gene for B27 is the major HLAlinked gene providing increased susceptibility to ankylosing spondylitis is the fact that the association with spondylitis is present in many populations throughout the world, differing ethnically and in particular in their prevalences of the various HLA antigens. The evidence for significant differences in the strong evidence that the products of the $\mathrm{MCH}$-linked immune response genes in the mouse are the Ia glucoprotein molecules themselves, ${ }^{11}$ being expressed on macrophages, B cells, and activated $T$ cells. If, as seems likely, this also applies in man the gene product of loci in the $\mathrm{D} / \mathrm{DR}$ region must have a key role in the development of the ability to discriminate self and non-self and hence in the development of an individual's immune responses. Knowledge of the key immunological events in the development of rheumatoid arthritis is at present fragmentary, and there is no evidence to point to any particular aspect of the immunological features characteristic of rheumatoid arthritis as being the most likely to be influenced by genes in the $D / D R$ region. Better definition of other loci in the $D / D R$ region may lead to identification of the actual genes whose product leads directly to increased susceptibility to the development of the disorder.

We are indebted to $\mathrm{Mr}$ Keith Gelsthorpe for his help in providing antisera. The work was supported by the Medical Research Committee of the Mersey Regional Health Authority.

\section{References}

${ }^{1}$ Stastny P. Association of the B-cell alloantigen DR 4 with rheumatoid arthritis. N Englf Med 1978;298:869-71.

2 Panayi GS, Wooley P, Batchelor JR. Genetic basis of rheumatoid disease: HLA antigens, disease manifestations, and toxic reactions to drugs. Br Med f 1978;ii:1326-8.

${ }^{3}$ Stastny P. Joint report: rheumatoid arthritis. In: Terasaki PI, ed. Histocompatibility testing. Los Angeles: UCLA Tissue Typing Laboratory, 1980:681-6.

4 Van Rood JJ, Van Leeuwen A, Ploen JS. Simultaneous detection of two cell populations by two-colour fluorescence and application to the recognition of B-cell determinants. Nature 1976;262:795-7.

${ }^{5}$ Haldane JBS. The estimation and significance of the logarithm of a ratio of frequencies. Ann Hum Genet $1955 ; 20: 309-11$.

${ }^{6} \mathrm{Karr}$ RW, Rodey GE, Lee T, Schwartz BD. Association of HLA-DRw4 with rheumatoid arthritis in black and white patients. Arthritis Rheum $1980 ; 23: 1241-4$.

7 Scherak O, Smolen JS, Mayr WR. Rheumatoid arthritis and B lymphocyte alloantigen HLA-DRw4. F Rheumatol 1980;7:9-12.

${ }^{8}$ Mercier P, Dallest R, Roux H. Association HLA-Dr et polyarthrite rheumatoide de l'adulte dans le sud de la France. Nouv Presse Med $1981 ; 9: 1037$.

- Silver J, Walker LE, Reisfeld RA, Pellegrino MA, Ferrone S. Structural studies of murine I-E and human DR antigens. Mol Immunol 1979; $17: 37-42$.

10 Delovitch TL, Falk JA. Evidence for structural homology between murine and human Ia antigens. Immunogenetics 1979;8:405-18.

11 Benacerraf B. Genetic control of the specificity of $T$ lymphocytes and their regulatory products. In: Fougereau M, Dausset J, eds. Immunology 80. Progress in immunology IV. London: Academic Press, 1980:419-31.

(Accepted 11 September 1981) 